$\xi=-1$

\title{
The Influence of Entrepreneurship Capability to Micro and Small Business Growth in Indonesian Fish Processing Industry
}

\author{
Sudrajati Ratnaningtyas ${ }^{1 *}$, Acip Sutardi ${ }^{2}$, Yogi Makbul ${ }^{3}$ \\ ${ }^{1}$ Institut Teknologi Bandung \\ ${ }^{2}$ Institut Teknologi Bandung \\ ${ }^{3}$ Institut Teknologi Bandung \\ *Corresponding author E-mail: sudrajati@sbm-itb.ac.id
}

\begin{abstract}
This study aims to measure the entrepreneurship capability and its influence on business growth in the fish processing industry which is a supporter of the culinary industry. There are three dimensions of entrepreneurship capability included in the model: entrepreneurial skills, management skills, and technical skills, with each factor. The research was conducted in fish production center in West Java Indonesia, in 2017. The research method used was survey method by Two-Stage Cluster Random sampling technique; and used primary and secondary data. Data analysis technique used Compound Annual Growth Rate (CAGR) to measure business growth, and Structural Equation Model (SEM) to analyze the influence of entrepreneurship on business growth. The results showed that communication, ability to take risk, innovative, change-oriented, persistent, proactiveness, committed, planning and goal setting, decision making, motivating, marketing, inner control, design, environment observation, critical path method, work break down structure are indicators appropriate to be a measure of entrepreneurial capability, especially for micro and small business manager. Entrepreneurship capability significantly influenced business growth at 95 percent confidence level. It means that when entrepreneurship capability is improved it will increase the business growth rate of micro and small business in the fish-based food processing industry in Indramayu Regency.
\end{abstract}

Keywords: Business Growth; Entrepreneurship Capability; Fish; Processing Industry; West Java

\section{Introduction}

According to Timmons \& Spinelli (1), entrepreneurship is a way of thinking, reasoning, and action to seize the opportunity, its approach is thorough and managed with leadership for value creation. According to Siropolis, N. (2) it is often that the failure of small businesses is caused by their management that is not well-prepared to cope with the increasing demands of skills knowledge, and the ability to manage more and more workers. There are also often gaps in managerial capacity to finance and develop the talents they need to live and grow. (3) (4), (5) argue that the development of managerial skills, entrepreneurial skills, technical skills will help entrepreneurs to achieve optimal results in business.

The problems of business growth management are also faced by micro and small-scale enterprises of food processing industry based on catch fish and fish cultivation in Indonesia in general. For the future development of the industry, the problems faced urgently to overcome, one of which is the entrepreneurial ability of the managers. In SMEs, it is usually that the manager is the owner of the business itself.

Development of food processing industry is needed in supporting the culinary industry. The culinary industry is one of the subsectors of the creative industry sector which began seriously developed by the Government of Indonesia starting in 2008, namely by drawing up a blueprint for the Creative Industry Development Plan Towards the Vision of the Creative Economy of Indonesia 2025 (6). In 2013 in the creative industry sector, the culinary sub-sector is the most significant contributor to GDP followed by the fashion industry and craft industry (7). By 2014, the creative economy has been able to contribute $7.1 \%$ to the national GDP, absorbthe workforce of about 12 million people, and contribute to the country's foreign exchange gain of $5.8 \%$. One of the steps taken by the government is to make Strategic Plan 2015-2019 (8).

Fish is a food industry raw materials that have advantages, due to the nutritional content, can be processed into various culinary variants, as well as abundant fishery resources in different regions in Indonesia. In 2014, Java Island was the second largest producer of marine fish with $1,173,264$ tons of production and third cultivation fish producer with 1,173,264 tons. In 2013 and 2014, sub-category growth of marine and fishery processing industries is $6.84 \%$ and $7.23 \%$ (9).

According to (10) the three regions in West Java Province with the most populations as fishermen are Indramayu Regency (40,746 people), Kabupaten Cirebon (22,969 people) after Indramayu (31,792 people), and Ciamis ( 181,848 people). This study aims to measure the entrepreneurship capability of micro and small business managers in the fish-based food processing industry in Indramayu Regency, and the growth of its business. Then test the influence of entrepreneurship capability to business growth in the fish processing industry which is a supporter of the culinary industry. 


\section{Literature Review}

The entrepreneurship capability can influence the small business growth; the statement is supported by many research. For example, the study of (11) found that entrepreneurship can influence the small business growth with innovation. When small businesses are increasingly innovative, it will grow faster. Another research is from (12), that is the growth of small business influences the internalization of entrepreneurship and innovation significantly. In a rural area with the challenge of a small market, poor infrastructure and lack of financial support is researched by (13), the result of the research showed that entrepreneurship is determinant of survival and business growth. The impact of innovation capability to the entrepreneurship capability in Indonesia researched by (14). The result showed that marketing, relational, capital, and innovation capability are significant and positive influences to entrepreneurship. According to the research of (15) the infrastructure increases the entrepreneurship and innovative capability. This research supports the theory that entrepreneurship capability affects small business growth.

The research on small business in fish industry shown that the success of a small business depends on entrepreneurship and community relationship (16). The research of (17) showed that small business in the fishing industry must use the "niche market" strategy to compete with the dominant corporate. That strategy needs entrepreneurship capability of the small business entrepreneur. In the rural area, small business of fishing industry must have fishing cooperative in order to have a competitive position (18). These studies conclude that small business in the fishing industry must have the entrepreneur capability.

The recent decades show that the fish processing industry has expanded. The research (19) explain that the fish processing industry in Portugal has expanded over decades. The increasing of fish processing industry is also reported by the research of $(20)$ that the factors of increasing of fish processing industry are globalization on fish industry and the increasing of experience of fisherman. According to (21) the increasing of fishing industry was caused by the fish population growth which is the impact of global warming.

Based on (22) skills needed for entrepreneurs can be classified into three, namely:

"Technical skills: writing, oral communication, monitoring environment, technical business management, technology, interpersonal, listening, ability to organize, network building, management style, coaching, being a team player. Business management skills: planning and goal setting, decision making, human relations, marketing, finance, accounting management, control, negotiation, venture launch, managing growth. Personal entrepreneurial skills: inner control/discipline, risk taker, innovative, change oriented, persistent, visionary leader".

According to (5) the entrepreneur must have the skill to increase the capacity. The essential entrepreneur skills are 1) technical skills, 2) managerial skills, 3) entrepreneurial skills, 4) personal maturity skills. The technical skills are necessary to produce product and service. Managerial skills are essential to organizing day by day management. Entrepreneur skills(23) are necessary to recognize the economic opportunity. Personal maturity skills are self-awareness, accountability, emotional skills, and creative skills. According to (24) the Entrepreneurship Skills sets from (5) as Fig.1.

Entrepreneurship skills will enable economic opportunities to be taken and can be run by businesses. Management skills consist of essential skills for operations and business management; although business ventures differ in size, type, and structure, generally business ventures typically have marketing, finance, general management, operations, administration and external affairs functions.
Technical skills is required in running a business. In setting up a new business venture, the entrepreneur must decide to divide the work into smaller, manageable projects that need the technicality to plan and control the entrepreneurial process. Employers should use project management techniques to plan and to control the project.

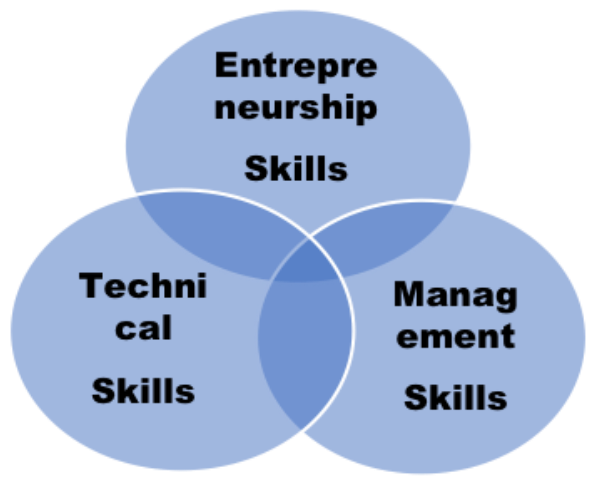

Fig.1. The (24) Model of the entrepreneurship skills sets adopted from (5)

According to (25) there is a relationship between entrepreneurship with technology and firm size. The relationship between innovative activity and business size has two ways of relationship that is through company activity based on factors owned by the company itself and industry. The company creates knowledge to produce innovations. As the result of the entrepreneurial process, building a new company can be an alternative way by balancing the value of their knowledge with the expected benefits of their activities within the organization.

\section{Methodology}

\subsection{Research Approach}

This research is verification research, with qualitative and quantitative approaches. Survey method is used in this research. Determination of research area is purposive, that is Indramayu Regency as a fish production center. The technique of determining the respondents is Two stages-cluster random sampling, which the elementary unit in the first stage is a kind of processed products made from raw fish, and in the second stage is a fish processing company. The unit of analysis is MSMEs in the fish-based food processing industry. The data used are primary data obtained from interviews using questionnaires, and secondary data by document collection and literature study. The variables used in this study are operationalized as in Table 1 .

\subsection{Sampling Techniques}

Sample determination technique is done by Two Stages-Cluster random sampling. The sampling frame at stage 1 is the list of fish producing sub-districts in Indramayu District, and the sampling frame at stage 2 contains the elementary units in the form of MSME fish makers in each sub-district selected in the first stage. Sample Size is determined by Simple random sampling according to (26).

Table 1:. Operationalization of variables

Variable: Entrepreneurship Capability ${ }^{*}(\xi)$ 


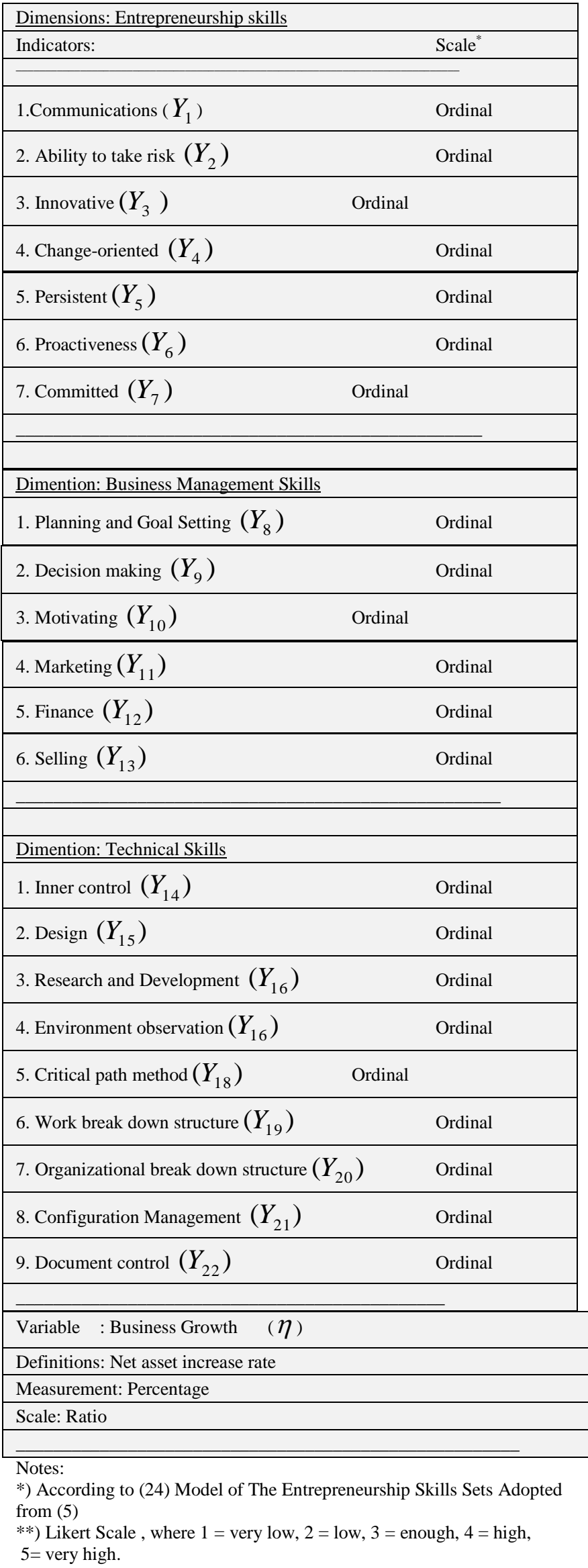

\section{$\mathrm{n}=$ sample size}

$\mathrm{t}=\mathrm{t}$ distribution value at $\alpha=0.05=1.64$

$\mathrm{S}=$ standard deviation of capital $=15,267,831$

$\mathrm{r}=$ tolerable relative error $=0.1$

$\bar{Y}=$ average of capital $=25,600,000$

$\mathrm{N}=$ population $=1652$

According to (27) when using SEM (Structural Equation Method), the minimum sample size is 5 times the number of indicators present in the model. In this study there are 22 indicators on independent variable plus one on a dependent variable then the minimum sample size is 115 units. Therefore, the result of the calculation according to the Ferdinand formula is greater than according to the Cochran formula, so that the sample size used is 115 .

\subsection{Data Analysis}

1. Business growth is calculated by using CAGR (Compound Annual Growth Rate).

$$
\left(\mathrm{I}_{2}-\mathrm{I}_{1)} / \mathrm{I}_{1} \wedge(1 / \mathrm{t})\right.
$$

Where: $\quad I_{1}=$ Net Assets at the beginning

$$
\begin{aligned}
\mathrm{I}_{2} & =\text { Net Assets at the end } \\
\mathrm{t} & =\text { year difference between the } 2^{\text {nd }} \text { year and } 1^{\text {st }} \text { year }
\end{aligned}
$$

2. The SEM model used is as follows

Notes:

$$
\begin{aligned}
\xi= & \text { Ksi is an exogenous latent variable that is entrepreneurship } \\
& \text { capability } \\
\eta= & \text { Eta is an endogenous variable that is business growth } \\
\beta= & \text { Beta is the coefficient of the influence of exogenous latent variable } \\
& \text { to endogenous variable, in this research is the influence of } \\
& \text { entrepreneurship capability to business growth }
\end{aligned}
$$

The structural equation is as follows:

$$
\eta=\beta \xi+\varsigma_{2}
$$

The specification of measurement model for construct of entrepreneurship capability variable is

$\mathrm{Y}_{k}=\lambda_{k}^{(Y)} \xi^{\xi}+\varepsilon_{k}$

Hypothesis tested:

$\mathrm{H}_{0}: \beta=0$

$\mathrm{H}_{1}: \quad \beta>0$ (entrepreneurship capability significantly influence to business growth)

Level of significance $(\alpha)=0.05$. Data were analyzed using SPSS

\section{Results and Findings}

\subsection{Reliability and Validity of the Measurement of En- trepreneurship Capability}

Based on the results of reliability test of construct entrepreneurship capability it can be seen that this contract is reliable, indicated by the high value of Cronbach's Alpha (0.828). However, among 22 indicators measured there are only 16 indicators are valid, it is indicated by the Corrected Item-. 
Table 2: Validity and reliability of measurement

\begin{tabular}{|c|c|c|c|c|}
\hline \multicolumn{3}{|l|}{ Cronbach's Alpha } & \multicolumn{2}{|l|}{$\mathrm{N}$ of Items } \\
\hline 0.828 & & & 22 & \\
\hline \multicolumn{5}{|c|}{ Item-Total Statistics } \\
\hline & $\begin{array}{l}\text { Scale } \\
\text { Mean if } \\
\text { Item } \\
\text { Deleted }\end{array}$ & $\begin{array}{l}\text { Scale } \\
\text { variance } \\
\text { if Item } \\
\text { Deleted }\end{array}$ & $\begin{array}{l}\text { Corrected } \\
\text { Item-Total } \\
\text { Correlation }\end{array}$ & $\begin{array}{l}\text { Cronbach's } \\
\text { Alpha if } \\
\text { Item Delet- } \\
\text { ed }\end{array}$ \\
\hline Y1 & 54.870 & 75.500 & 0.486 & 0.816 \\
\hline Y2 & 56.200 & 76.267 & 0.406 & 0.820 \\
\hline Y3 & 56.504 & 77.164 & 0.441 & 0.819 \\
\hline Y4 & 55.000 & 78.228 & 0.690 & 0.818 \\
\hline Y5 & 55.791 & 66.254 & 0.598 & 0.802 \\
\hline Y6 & 55.383 & 74.694 & 0.598 & 0.812 \\
\hline Y7 & 54.730 & 76.146 & 0.516 & 0.816 \\
\hline Y8 & 55.844 & 72.098 & 0.605 & 0.809 \\
\hline Y9 & 55.017 & 75.052 & 0.491 & 0.816 \\
\hline Y10 & 54.374 & 77.815 & 0.498 & 0.818 \\
\hline Y11 & 55.583 & 76.877 & 0.401 & 0.820 \\
\hline Y12 & 55.435 & 83.263 & 0.062 & 0.831 \\
\hline Y13 & 56.339 & 85.577 & -0.129 & 0.845 \\
\hline Y14 & 55.157 & 77.607 & 0.424 & 0.820 \\
\hline Y15 & 56.139 & 80.840 & 0.437 & 0.823 \\
\hline Y16 & 54.991 & 78.728 & 0.290 & 0.825 \\
\hline Y17 & 55.539 & 73.409 & 0.581 & 0.811 \\
\hline Y18 & 55.009 & 74.535 & 0.521 & 0.814 \\
\hline Y19 & 55.148 & 75.987 & 0.501 & 0.816 \\
\hline $\mathrm{Y} 20$ & 55.478 & 81.392 & 0.133 & 0.834 \\
\hline Y21 & 55.409 & 81.367 & 0.082 & 0.838 \\
\hline Y22 & 54.791 & 82.675 & 0.088 & 0.831 \\
\hline
\end{tabular}

Total Correlation value greater than 3. There are 6 invalid indicators, namely Y12 (Finance), Y13 (Selling), Y16 (Research and Development), Y20 (Organizational break down structure), Y21 (Configuration management), Y22 (Document control). It can be seen in the Table 2In the further stages of analysis, these six indicators are excluded from the Entrepreneurship Capability construct model. This invalidity caused by the questionnaire design that is not appropriate to elaborate data from the respondent, misinterpretation that occurs between what is asked by the enumerator with that understood by the respondent, and other factors.

\subsection{Measurement Results of the Entrepreneurship Capa- bility and the Testing of the Influence of Entrepre- neurship Capability to Business Growth}

According to the results of the analysis, it can be concluded that a total of 16 indicators are able to explain this entrepreneurial skills variable clearly. All of these indicators show a positive estimation coefficient

Table 3: Estimated results of indicators of the entrepreneurship capability (confirmatory factor analyses) and the testing of the influence of entrepreneurship capability to business growth

\begin{tabular}{|l|l|l|l|l|}
\hline & Estimate of & Estimate of & C.R. & P \\
\hline Weights & $\begin{array}{l}\text { Regression } \\
\text { S19 } \square \mathrm{Y}\end{array}$ & 1 & Standardized & \\
\hline $\mathrm{Y} 18 \square \mathrm{Y}$ & 1.014 & 0.589 & & \\
\hline $\mathrm{Y} 17 \square \mathrm{Y}$ & 1.317 & 0.528 & 4.958 & $* * *$ \\
\hline $\mathrm{Y} 15 \square \mathrm{Y}$ & 0.342 & 0.673 & 6.002 & $* * *$ \\
\hline $\mathrm{Y} 14 \square \mathrm{Y}$ & 0.694 & 0.425 & 4.159 & $* * *$ \\
\hline $\mathrm{Y} 11 \square \mathrm{Y}$ & 0.874 & 0.439 & 4.273 & $* * *$ \\
\hline $\mathrm{Y} 10 \square \mathrm{Y}$ & 0.614 & 0.479 & 4.59 & $* * *$ \\
\hline $\mathrm{Y} 9 \square \mathrm{Y}$ & 1.012 & 0.459 & 4.361 & $* * *$ \\
\hline $\mathrm{Y} 8 \square \mathrm{Y}$ & 1.504 & 0.529 & 4.956 & $* * *$ \\
\hline $\mathrm{Y} 7 \square \mathrm{Y}$ & 0.829 & 0.71 & 4.956 & $* * *$ \\
\hline $\mathrm{Y} 6 \square \mathrm{Y}$ & 1.133 & 0.511 & 4.832 & $* * *$ \\
\hline $\mathrm{Y} 5 \square \mathrm{Y}$ & 2.05 & 0.673 & 5.983 & $* * *$ \\
\hline $\mathrm{Y} 4 \square \mathrm{Y}$ & 0.682 & 0.729 & 6.326 & $* * *$ \\
\hline $\mathrm{Y} 3 \square \mathrm{Y}$ & 0.812 & 0.567 & 5.28 & $* * *$ \\
\hline $\mathrm{Y} 2 \square \mathrm{Y}$ & 0.864 & 0.499 & 4.746 & $* * *$ \\
\hline $\mathrm{Y} 1 \square \mathrm{Y}$ & 0.972 & 0.444 & 4.304 & $* * *$ \\
\hline Total & & 0.529 & 4.999 & $* * *$ \\
\hline $\mathrm{N} \leftarrow \mathrm{Y}$ & 38.668 & 8.783 & 2.824 & \\
\hline
\end{tabular}

Referring to Table 3, all indicators have a significant effect on construct. It is indicated by high $\mathrm{CR}$ or $\mathrm{p}$ value $<0.05(* * *)$. Thus all 16 indicators above are the right indicators to measure Entrepreneurship Capability.

Indicators that are very capable of measuring the dimensions of technical skills in Entrepreneurship Capability variables are: Environment Observation, Critical Path Method, and Work Break down Structure. It is shown by the estimated coefficient of standardized regression weight above 0.50 and positive (28).

In the dimensions of business management skills, there are 2 indicators that show positive estimation coefficient and more than 0.50 which are Planning and Goal Setting, Decision Making which means strong influence.

Indicators in the entrepreneurship skills dimension almost all show a high and positive estimation coefficient, except Ability to take a risk and Innovative. It means that Communication, Change Oriented, Persistent, Proactiveness, Committed are the right indicators of the entrepreneurship skill dimension.

In addition to the significance and magnitude of the coefficient of estimation of each indicator, then according to (28) can also be seen from construct reliability. The reliability of the construct can show whether the indicators in the overall construct model are able to explain it construct.

The reliability of the construct is calculated by the following formula:

\section{(Total of standard loading) $^{2}$}

Construct reliability = ----

(Total of standard loading)

+ Total measurement error

Total of standard loading $=$ Sum of Standardize Regression Weight

Measurement error $=1-(\text { standard loading })^{2}$

Based on the formula, then it can be further calculated:

Reliability of construct of Entrepreneurship Capability $=(8.783)$ $/(8.783)+(2.824)=0.96$. The entrepreneurship construct shows a higher reliability value than recommended $(0.70)$. In other words, the indicators in the constructed model have been convincingly able to explain the construct.

Another important thing to note is the existing condition of the level achieved by Micro and Small Business Managers in The Fish-Based Food Processing Industry in Indramayu Regency, West Java Region on each skill dimension and Indicator. It is useful to know whether the indicators contribute to Entrepreneurship Capability but the condition is still low level on the Likert scale. If it is still low, then it takes effort to improve it.

Table 4: Level achieved by micro and small business managers in the fishbased food processing industry in Indramayu Regency, West Java region on each skill dimension and indicator

\begin{tabular}{|l|l|l|l|l|}
\hline Dimension/Indicator & Minimum & Maximum & Mode & Criterion \\
\hline $\begin{array}{l}\text { Entrepreneurship } \\
\text { Skills }\end{array}$ & & & & \\
\hline $\begin{array}{l}\text { 1. Communication } \\
\text { (Y1) }\end{array}$ & 1 & 5 & 4 & high \\
\hline $\begin{array}{l}\text { 2. Ability to Take } \\
\text { Risk (Y2) }\end{array}$ & 1 & 4 & 1 & very low \\
\hline 3. Innovative (Y3) & 1 & 4 & 1 & very low \\
\hline $\begin{array}{l}\text { 4. Change Oriented } \\
\text { (Y4) }\end{array}$ & 1 & 5 & 3 & enough \\
\hline 5. Persistent (Y5) & 1 & 5 & 1 & very low \\
\hline 6. Proactiveness (Y6) & 1 & 5 & 2 & low \\
\hline 7. Committed (Y7) & 2 & 5 & 3 & enough \\
\hline
\end{tabular}




\begin{tabular}{|l|l|l|l|l|}
\hline Management Skills & & & & \\
\hline $\begin{array}{l}\text { 1. Planning and Goal } \\
\text { Setting (Y8) }\end{array}$ & 1 & 5 & 2 & low \\
\hline $\begin{array}{l}\text { 2. Decision Making } \\
\text { (Y9) }\end{array}$ & 2 & 5 & 4 & high \\
\hline 3. Motivating (Y10) & 2 & 5 & 4 & high \\
\hline 4. Marketing (Y11) & 1 & 4 & 2 & low \\
\hline Technical Skills & & & & enough \\
\hline 1. Inner Control (Y14) & 1 & 4 & 3 & low \\
\hline 2. Design (Y15) & 1 & 3 & 2 & low \\
\hline $\begin{array}{l}\text { 3. Environment Ob- } \\
\text { servation (Y17) }\end{array}$ & 1 & 4 & 2 & low \\
\hline $\begin{array}{l}\text { 4. Critical Path Meth- } \\
\text { od (Y18) }\end{array}$ & 1 & 5 & 2 & enough \\
\hline $\begin{array}{l}\text { 5. Work Break Down } \\
\text { Structure (Y19) }\end{array}$ & 1 & 4 & 3 & \\
\hline
\end{tabular}

Table 4 shows that it can be assumed that there are only three indicators that have a high level that is: Communication, Decision Making, and Motivating. It should be noted that the Persistent and Planning and Goal Setting indicators that have a strong influence on Entrepreneurship capability, but the condition is still very low and low. There are lots of opportunities to increase Entrepreneurship Capability of micro and small business managers in the fishbased food processing industry in Indramayu Regency through efforts to improve indicators that are still low and very low.

\section{Conclusion, Suggestion, and Limitation}

\subsection{Conclusion}

1. Communication, ability to take risk, innovative, changeoriented, persistent, proactiveness, committed, planning and goal setting, decision making, motivating, marketing, inner control, design, environment observation, critical path method, work break down structure are indicators appropriate to be a measure of Entrepreneurial Capability, especially for micro and small business managers in the fish-based food processing industry in Indramayu Regency, West Java Region, Indonesia.

2. Levels of achievement of each indicator based on the Likert scale generally exist at various levels. In more detail the mode for each indicator is as follows: Communication at level 4 (40\% of entrepreneurs), ability to take risk at level $1(53 \%)$, innovative at level $1(67 \%)$, change-oriented at level $3(74 \%)$, persistent at level 1 (49\%), proactiveness at level $2(52 \%)$, committed at level $3(48 \%)$, planning and goal setting at level $2(44 \%)$, decision making at level $4(42 \%)$, motivating at level $4(49 \%)$, marketing $2(48 \%)$, inner control at level $3(41 \%)$ design at level $2(89 \%)$, environment observation at level 2 $(60 \%)$, critical path method at level $2(40 \%)$, and work break down structure at level $3(37 \%)$.

3. Entrepreneurship capability significantly influenced business growth. It means that when Entrepreneurship capability is improved it will increase the business growth rate of micro and small business in the fish-based food processing industry in Indramayu Regency, West Java Region Indonesia.

\subsection{Suggestion}

Need to make efforts to improve entrepreneurial skills, management skills, and technical skills in order Entrepreneurship Capability of micro and small business managers in the fish-based food processing industry in Indramayu Regency, West Java Region also increased. These aspects are still weak should be the focus of attention, namely the aspect of Ability to take risk, Innovation, Persistency, Proactiveness (in the dimension of entrepreneurial skills), Planning and goal setting, Marketing (in the dimension of management skills), as well as in terms of Design, Environment observation, Critical path method (in terms of technical skills). The success of these efforts becomes leverage for improving their business growth.

\subsection{Limitation}

In this study there is no improvement in research instruments and research procedures, so there are some indicators of Entrepreneurship Capability construct that are not included in the model developed by (24) which is for the indicators of Finance, Selling, Research and Development, Organizational break down structure, Configuration management, Document control. This causes the model analyzed in this study cannot reveal the contribution and significance of these indicators on forming the Entrepreneurship Capability construct. The further implication is that in this study it is not known whether these indicators strengthen or weaken the influence of Entrepreneurship Capability on Business Growth.

\section{References}

[1] Timmons JA, Spinelli S. New Venture Creation: Entrepreneurship for the 21st Century. Vol. 2009, Business. 2016. XXX, 658 p.

[2] Siropolis N. Small Business Management-A guide to Entrepreneurship. Boston: Houghton Mifflin Company; 1994.

[3] Hisrich R, Peters M. Entrepreneurship: Starting, Developing and Managing a New Enterprise. Strategic Change. 1995.

[4] Newenhuizen C. Business Management for Entrepreneurs. Cape Town: Juta and Co.Ltd.; 2009.

[5] Kutzhanova N, Lyons TS, Lichtenstein GA. Skill-Based Development of Entrepreneurs and the Role of Personal and Peer Group Coaching in Enterprise Development. Econ Dev Q. 2009 Aug;23(3):193-210.

[6] Departemen Perdagangan. Pengembangan Ekonomi Kreatif Indonesia 2025, Rencana Pengembangan Ekonomi Kreatif 2009. 2015. 2008.

[7] Kementerian Pariwisata dan Ekonomi Kreatif. Indonesia Kreatif. Jakarta; 2013.

[8] Kementerian Koordinator Bidang Perekonomian. Rencana Strategis 2015-2019. Jakarta; 2015.

[9] Kementerian Kelautan dan Perikanan. Analisa Data Pokok Kelautan dan Perikanan 2015. Jakarta; 2015.

[10] Pusat Data dan Analisis Pembangunan Jawa Barat. Buku Data Pembangunan Tahun 2013. Bandung; 2013.

[11] Baumane-Vitolina, Ilona; Cals I. Theoretical Framework for Using Resource Based View In The Analysis Of SME Innovations. Eur Sci J. 2013;1(1):174-82.

[12] Kanugi JN. Factors Influencing the Performance of Growth Oriented Small and Medium Enterprises in Thika Sub-County. Strateg J Bus Chang Manag. 2017;4(2):180-96.

[13] Lekhanya LM. Determinants of survival and growth of small and medium enterprises in rural KwaZulu - Natal. 2016.

[14] Sulistyo HS. Innovation capability of SMEs through entrepreneurship, marketing capability, relational capital and empowerment. Asia Pacific Manag Rev. 2016;21(4):196-203.

[15] Roig-Tierno, Norat; Alcázar, Joaquín; Ribeiro-Navarretec S. Use of infrastructures to support innovative entrepreneurship and business growth. J Bus Res. 2015;68(11):2290-4.

[16] Brookfield, Katherine; Gray, Tim; Hatchard J. The concept of fisheries-dependent communities: A comparative analysis of four UK case studies: Shetland, Peterhead, North Shields and Lowestoft. Fish Res. 2005;72(1):55-69.

[17] Knutson P. Escaping the corporate net: Pragmatics of small boat direct marketing in the U.S. Salmon fishing industry of the Northeastern pacific. Mar Policy. 2017;80:123-9.

[18] Samian, Masoud; Saadi, Heshmatollah; Mirzaeia, Khalil,; Ansari, Elham; Ahmadihagh, Esmaeil; Soleymani A. The role of fishing cooperatives on social - Economic and cultural development of rural areas of Bord Khun city of Bushehr, Iran. J Saudi Soc Agric Sci. 2017;16(2):178-83.

[19] Bjørndal, Trond; Brasão, Ana; Ramos, Jorge; Tusvike A. Fish processing in Portugal: An industry in expansion. Mar Policy. 2016;72:94-106.

[20] Arbo, P; Hersoug B. The globalization of the fishing industry and the case of Finnmark. Mar Policy. 1997;21(2):121-42.

[21] Eide, Arne; Heen K. Economic impacts of global warming: A study of the fishing industry in North Norway. Fish Res. 2002;56(3):26174.

[22] Hisrich, R.D.; Peters MP. Entrepreneurship: Starting, Developing, and Managing a New Enterprise. Mc.Graw-Hill,Inc.; 1995.

[23] Shahverdi M, Ismail K, Qureshi MI. The effect of perceived 
barriers on social entrepreneurship intention in Malaysian universities: The moderating role of education. Manag Sci Lett [Internet]. 2018;8:341-52. Available from: http://www.growingscience.com/msl/Vol8/msl_2018_27.pdf

[24] Cooney TM. Entrepreneurship Skills for Growth-Orientated Businesses: Report for the Workshop on 'Skills Development for SMEs and Entrepreneurship'. Copenhagen, 28 November 2012. 2012.

[25] Zoltan, J.; Audretsch DB. Innovation and Technological Change. In: Handbook of Entrepreneurship Research< An Interdisciplinary Survey and Introduction. New York: Springer Science+Business Media, Inc.; 2005. p. 55-79.

[26] Cochran WG. Sampling Techniques. Wiley Series in Probability and Mathematical Statistics Applied. 1977.

[27] Ferdinand A. Structural Equation Modelling -Dalam Penelitian Managemen. Semarang: Fakultas Ekonomi Undip; 2002.

[28] Ghozali I. Model Persamaan Struktural: Konsep dan Aplikasi dengan Program Amos Ver.5.0. Semarang: Badan Penerbit Universitas Diponegoro; 2004. 